\title{
PORTINARI LEITOR*
}

Annateresa Fabris**

RESUMO: Como ilustrador Portinari distingue-se por uma leitura da obra fiel ao espírito do autor. É o que comprovam as ilustrações realizadas para obras de Machado de Assis, Cervantes e Staden, nas quais se percebe uma profunda identificação entre texto e imagem.

Palavras-chave: ilustração moderna, Portinari, Machado de Assis, Cervantes, Staden.

\section{1 - De Machado de Assis}

Arte "em forma de livro", nos dizeres de Riva Castleman, ${ }^{1}$ a colaboração entre artistas plásticos e escritores tem sido uma constante no século XX. Para tanto, foi necessário vencer a resistência dos bibliófilos, que não apenas davam preferência à tradicional técnica da xilogravura, como olhavam com desconfiança o trabalho dos pintores, que tomavam liberdades "incompativeis com aquele 'acabado' que faz a beleza do livro ilustrado". ${ }^{2}$

(*) Texto originalmente publicado no catálogo da exposição Portinari leitor (São Paulo: Museu de Arte Moderna, 1996).

(*) Professora do Programa de Pós-Graduação em Artes da ECA-USP.

(1) Artistas modernos enquanto ilustradores. Nova Iorque, Museu de Arte Moderna, 1981, p. 18.

(2) A Vollard, Ricordi di un mercante di quadri. Torino, Einaudi, 1978, p. 221. 
Inaugurada pela parceria Goethe/Delacroix (Fausto, 1828), a moderna concepção de ilustração ganha reforço no começo do século XX, quando as vanguardas históricas contrapõem aos produtos anônimos da indústria editorial aquelas "criações pessoais" que resultam do trabalho conjunto do artista, do escritor e do diagramador. Surgem inclusive editoras especializadas nesse tipo de produção, como é o caso de Vollard (Parallèlement de Verlaine/Bonnard, 1900; As Flores do Mal com ilustrações de Émile Bernard, 1914); Kahnweiler (L'Enchanteur Pourrissant de Apollinaire/Derain, 1906); a Cranach Presse, fundada em Weimar em 1913, de acordo com os princípios da tradição gráfica inglesa dos fins do século XIX (As Éclogas de Virgílio/Maillol, 1927); Skira (As Metamorfoses de Ovídio/Picasso, 1931); The Limited Editions Club, cuja publicação mais ambiciosa é o Ulisses, ilustrado por Matisse, mais de acordo com a visão de Homero do que com aquela de Joyce (1935).

A diferença entre a atitude do artista e aquela do ilustrador é definida por Riva Castleman a partir da contraposição entre "iluminar" e "ilustrar". Se, no caso do ilustrador, a relação entre palavra e imagem é sobretudo descritiva, o artista, ao contrário, busca essencialmente um resultado estético. Ou seja, a "iluminação dos sentidos e sentimentos de uma estória enriquece enormemente a experiência de se formar imagens mentais, a qual uma ilustração literal poderia efetivamente abafar. Portanto, embora a ilustração de textos seja a contribuição do artista aos livros, o que torna tão marcantes os exemplos mais destacados desta atividade é o diálogo equilibrado estabelecido entre as duas formas criativas. Quando o autor e o artista trabalham juntos, ou quando o artista também é o autor, geralmente ocorre uma grande harmonia entre intenção e resultado". ${ }^{3}$

(3) Artistas modernos enquanto ilustradores, cit., p. 17. 
É essa visão moderna de "iluminador" que Lúcia Miguel Pereira oferece de Portinari, ao resenhar, em agosto de 1944, o lançamento de Memórias Póstumas de Brás Cubas pela Sociedade dos Cem Bibliófilos do Brasil. Fundada em 1943 por iniciativa de Raymundo Ottoni de Castro Maya, ${ }^{4}$ a Sociedade lança no ano seguinte sua primeira publicação, resultado da leitura que o pintor faz da obra de Machado de Assis.

Os termos usados pela crítica são bem sintomáticos da atitude moderna de Portinari, posto que faz referência à "interpretação de uma arte pela outra", à "demonstração de sua equivalência". A descrição do procedimento adotado pelo pintor dá claramente a idéia daquele diálogo de que fala Riva Castleman. Lúcia Miguel Pereira mostra um Portinari que "procurou, antes de mais nada, entender o modo de ser de Machado de Assis, penetrar-lhe o espirito, assimilar-lhe os processos de composição; foi um estudo lento, paciente, minucioso, de que resultou a sua perfeita identificação com o romancista. O pintor, que não recua diante de deformações ousadas e exuberantes efeitos de coloridos, fez-se delicado, sóbrio, comedido, adotando a economia de traços do autor, sem contudo nada sacrificar da sua personalidade. Portinari, refreado por Machado, é sempre Portinari, como Machado, plasticizado por Portinari, é sempre Machado. Combinam-se, completam-se, mas não se confundem".

Verdadeiro intérprete de Machado de Assis, Portinari proporciona com suas ilustrações uma "análise crítica" do romance. Dele conserva "a atmosfera, aquele misto de compostura e libertinagem intelectual, de ironia puxando para a amargura, e graça de uma elaborada simplicidade, de tédio e amor à vida". Para ser fiel ao escritor, o pintor "restringiu, ou melhor, dirigiu a sua imaginação, fazendo uma re-criação,

(4) Para dados ulteriores sobre a Sociedade dos Cem Bibliófilos do Brasil, ver: C. H. Knychala, O livro de arte brasileiro. Rio de Janeiro, Presença; Brasília, INL, 1983, p. 75-78, 92-96, 109-111. 
coisa mais difícil, e no caso mais valiosa, do que a criação espontânea". ${ }^{5}$

Memórias Póstumas de Brás Cubas resultou num livro de 316 páginas, com 7 águas-fortes de página inteira, 25 retratos e 53 desenhos a nanquim, escolhidos a partir de inúmeros estudos feitos pelo artista. ${ }^{6} \mathrm{O}$ interesse de Castro Maya em conseguir uma publicação requintada e de boa qualidade é testemunhado por várias cartas encaminhadas ao artista, que realiza o trabalho em Brodósqui no inverno-primavera de 1943. A questão da identificação dos personagens, discutida em diversas cartas, dá bem uma idéia do cuidado que cerca o planejamento do livro. A 20 de setembro, escreve Castro Maya:

"Com referência aos personagens lembramos também que talvez fosse melhor identificá-los com o nome, pois a simples colocação em algum caso é capaz de trazer confusão. Eu penso que tínhamos falado em pôr o nome no índice, mas estas páginas em clichê não levam número!!

Qual tua opinião? Se formos colocar o nome com que tipo de letra? Penso que em letra de forma não ficaria bem só em manuscrito, mas isto deveria ser com sua letra..."

A questão volta a ser discutida a 24 de setembro até ganhar uma definição a 14 de outubro. Dando conta de uma reunião da Comissão Executiva da Sociedade dos Cem Bibliófilos do Brasil, Castro Maya comunica a seguinte decisão a Portinari:

(5) L. Miguel Pereira, "Machado de Assis e Portinari". Correio da Manhã, Rio de Janeiro, 13 ago. 1944.

(6) A tiragem do livro é de 119 exemplares: 100 para os sócios e os restantes distribuídos de acordo com o artigo II dos Estatutos da Sociedade dos Cem Bibliófilos do Brasil. Em 1979, por encomenda da Rede Globo, a editora Rocco publica uma edição fac-similar da obra. À diferença do original, que vinha em cadernos soltos, a edição fac-similar é costurada e encadernada. A colocação das 7 águas-fortes segue as indicações dadas por Portinari no caso de encadernação. Rubem Braga e Jacques Kalbourian são responsáveis pela produção da edição, que conta com uma tiragem de 1000 exemplares. 
"Foi discutido em $1^{\circ}$ lugar o caso dos nomes nos desenhos. Fizemos diversos ensaios com letra de imprensa e todos foram de opinião que indiscutivelmente ficaria melhor se fossem escritos pelo artista que os executou. Se V. estiver de acordo conosco, poderá mandar por registrado com urgência (pois os clichês estão parados por causa disto) o nome de cada um deles, escrito a nanquim num pedaço de papel branco. Na confecção do clichê colocaríamos o nome de acordo com cada desenho (junto a lista dos personagens que V. criou). Estando estes com os respectivos nomes, será mais fácil colocar-se no livro, o que ficará mais harmônico, pois é claro que nas primeiras 100 páginas quase que aparecem todos os personagens e o fim ficaria muito vazio".

É justamente essa a solução a vingar, como mostra a carta de 22 de outubro:

"Confirmo minha carta de 14 que espero ter chegado às suas mãos, pois já recebi o nome dos personagens. Juntamente com Cypriano estive recortando os nomes e colocando nos respectivos desenhos. Faltaram porém 3, que penso ficarão melhor desta maneira: em vez de Sr. Dutra (pai de Virgília) penso que deveríamos escrever Conselheiro Dutra. E em vez de Tio de Brás Cubas e tio de Brás Cubas (padre), penso que ficaria melhor Tio João e Tio (padre)". ${ }^{7}$

Ao interpretar Machado de Assis, Portinari introjeta a economia peculiar ao estilo do escritor, sem que isso signifique abdicar de seu interesse pela deformação ou deixar de enveredar por uma visão surrealista, como a que caracteriza a gravura O Delírio, relativa ao VII capítulo de Memórias Póstu-

(7) A correspondência citada foi localizada nos arquivos do Projeto Portinari (Rio de Janeiro), graças a um auxilio-pesquisa concedido pela FAPESP, à qual vão meus agradecimentos, em janeiro de 1991. Cypriano, citado na última carta, é Cypriano Amoroso Costa, membro da Comissão Executiva da Sociedade dos Cem Bibliófilos do Brasil, ao lado do próprio Castro Maya e de Dom Pedro de Orleans e Bragança, Afrânio Peixoto e Max Fischer. 
mas de Brás Cubas. A viagem do protagonista pela história da humanidade, com "a sua porção de sombra e de luz, de apatia e de combate, de verdade e de erro, e o seu cortejo de sistemas, de idéias novas, de novas ilusões", 8 é condensada pelo pintor na imagem do homem cavalgando um hipopótamo, definido por um desenho sumário que melhor caracteriza sua deformidade e sublinha a diferença entre um e outro. Todo o delírio é contido por essa imagem de grande impacto visual, pois o hipopótamo do começo do delírio e o gato do final se encontram lado a lado, como que para enfeixar a concepção entre irônica e amarga de Machado de Assis sobre o embate entre o extraordinário e o cotidiano. O hipopótamo motejador, ao qual o escritor só confere essa qualificação adjetiva, tem um contraponto em Sultão, o gato de Brás Cubas, "que brincava à porta da alcova, com uma bola de papel...". 9

O desenho econômico, que apanha em poucos traços episódios, situações e fisionomias, é a característica central da interpretação portinariana de Memórias Póstumas de Brás Cubas. O episódio da borboleta preta, que ocupa o XXXI capítulo do livro, é resumido no desenho Mão com Borboleta, no qual o esvoaçar do inseto pelo quarto, os vários encontros com o protagonista, o ataque que resulta em sua morte e a tentativa de restitui-la à vida ganham uma condensação paradigmática no último episódio, no qual ecoam as palavras de Machado de Assis, "tomei-a na palma da mão". ${ }^{10}$

Embora Antonio Bento fale de traçados quase realistas em Memórias Póstumas de Brás Cubas e O Alienista, ${ }^{11}$ não é isso, contudo, que se impõe nos dois conjuntos de ilustra-

(8) Machado de Assis, Memórias póstumas de Brás Cubas - Dom Casmurro. São Paulo, Abril Cultural, 1971, p. 25.

(9) Id., p. 27.

(10) Id., p. 62 .

(11) 30 desenhos de Portinari. Lisboa, Centro de Arte Moderna - Fundação Calouste Gulbenkian, set. 1987, s.p. 
ções. Portinari opta, via de regra, pela estilização, por uma instantaneidade que foge da descrição realista e se resolve em poucas linhas expressivas e densas de significado. Lúcia Miguel Pereira fala de ilustrações "exatas, sem um detalhe a mais ou a menos, como as quereria ver gravadas Machado de Assis, isto é, sem a preocupação anti-artística de reproduzir fotograficamente a natureza, mas com o empenho cuidadoso de captar todos os traços essenciais". ${ }^{12}$

As imagens a que a crítica faz referência são as águasfortes e a ilustração Camarote. Entre as primeiras, duas pelo menos, merecem considerações ulteriores, por estarem bem próximas da pintura de Portinari, Marcela e A Bordo. A apresentação da cortesã, em cuja dupla face Lúcia Miguel Pereira detecta "um estupendo achado"13 do pintor, evoca aquela plástica monumental de algumas obras da década de 30, derivada do diálogo com o Picasso neoclássico e retomada no painel São Francisco se Despojando das Vestes, da igreja de Pampulha. A Bordo, por sua vez, não deixa de apresentar semelhanças com os quatro painéis de Washington, além de exibir um estilema típico da plástica portinariana: a deformação expressiva de pés e mãos.

A "linda Marcela" de Machado de Assis, "boa moça, lépida, sem escrúpulos, um pouco tolhida pela austeridade do tempo (...); luxuosa, impaciente, amiga de dinheiro e de rapazes" e, posteriormente, tendo "a flor das graças" destruída pela doença e por uma velhice precoce, que conferiam ao rosto um aspecto de "lixa grossa, enormemente grossa", ${ }^{14}$ é apresentada simultaneamente por Portinari nos dois momentos cruciais de sua existência. Semi-despida, exibindo sua formosura nas coxas grossas e num seio saltado, tem o rosto dividido em duas metades assimétricas. A linda Marcela, re-

\footnotetext{
(12) L. Miguel Pereira, cit.

(13) Id.

${ }^{(14)}$ Machado de Assis, cit., p. 38-39, 68-69.
} 
tratada de perfil, convive com a Marcela bexiguenta, cujo meio rosto vem se encaixar na face do momento feliz. Traço de união entre os dois momentos, os olhos, que o pintor parece interpretar de acordo com o estado de espírito de Brás Cubas, incapaz de perceber a verdadeira natureza da antiga amada: ao invés de enxergar neles "a flama da cobiça", o protagonista tem diante de si os "olhos da primeira edição". ${ }^{15}$

Em A Bordo, o artista focaliza a figura do doido durante a cena do temporal, quando "erguia ao ar as mãos ossudas, (...) e ria muito, desesperadamente". ${ }^{16}$ Não dispondo de nenhuma descrição física fornecida por Machado de Assis, Portinari cria uma imagem sintética, concentrando a expressão do desatino num rosto convulso, de olhos arregalados e boca entreaberta e sublinhando a tensão da cena com as mãos erguidas e espalmadas praticamente no mesmo nível do mar, por ter sido abolida qualquer idéia de perspectiva.

O fato de o doido não ter ganho qualquer descrição fisica no romance faz parte da economia expressiva de que Machado de Assis se utiliza e de sua estratégia de sugerir o tipo pelas situações nas quais desempenha um papel significativo. É o que se nota, por exemplo, nas caracterizações propostas por Lúcia Miguel Pereira para a galeria de retratos masculinos, considerada o melhor momento da interpretação que Portinari dá à obra de Machado de Assis:

\footnotetext{
"Cada um deles parece viver nos desenhos com os seus tiques, os seus costumes, a sua fisionomia física e moral. Não seria necessário pôr-lhes os nomes para que os reconhecessem os leitores de Brás Cubas. Vemo-los desfilar, e logo percebemos que aquele fidalgote emproado só pode ser o pai do herói, com os seus fumos de nobreza; lá vem o tio João, mal reprimindo o riso em que se desmanchara ao contar às negras grosseiras anedotas, enquanto o tio Ildefonso se afasta, escandalizado e austero; surge Vilaça,
}

\footnotetext{
(15) Id., p. 69.

(16) Id., p. 47
} 
com a falsa gravidade de hipócrita e o falso brilho do poeta de sobremesa, contrastando com a honesta e obscura rabugice do professor Barata; o conselheiro Dutra ostenta a sua jovialidade e as suas manhas eleitorais, mas já em Lobo Neves há alguma coisa de tenso, a trair o ambicioso; esta cara finória, sabemos que é a de Cotrim, ávido e dissimulado; o poeta Luís Dutra não esconde a melancolia dos que duvidam de si, e em Quincas Borba, o olhar alucinado, deixa entrever abismos de loucura, sobre os quais dança o raciocínio; Nhonhô encarna a adolescência pura, Garcez a velhice ridicula; em Viegas ouve-se o ronco da asma e vê-se a garra da avareza, ao passo que Damasceno é só simpatia e vulgaridade.

Deixei de propósito para o fim o Brás Cubas; Portinari representou-o moço, bela cabeça a que as modas do tempo emprestam um ar romântico, corrigido pela frieza da expressão e pela lucidez do olhar; é a 'flor dos Cubas', o amante feliz de Marcela e Virgília, o gozador egoísta e seu tanto cínico, ainda não tocado, porém, pelas 'rabugens de pessimismo" ". ${ }^{17}$

Embora todos os retratos masculinos sejam realmente bem delineados, há alguns que se sobressaem por suas qualidades plásticas e pela capacidade de introspecção demonstrada pelo artista: Viegas, de olhos e boca cerrados, a sublinharem seu estado de não disponibilidade perante o mundo; Quincas Borba, cuja fisionomia austera e perdida ao mesmo tempo deixa entrever uma profunda perturbação; Cotrim, cujo rosto denota a superficialidade com a qual encara a vida; o professor Barata, de expressão ensimesmada, cuja expressividade é realçada pela rede de rugas que sulca suas faces e pela barba e pelos cabelos em desalinho; Vilaça, verdadeiro emaranhado de linhas e traços, cujo olhar fugidio denuncia a duplicidade de seu caráter.

As figuras femininas, como bem notou Lúcia Miguel Pereira, exibem, ao contrário, uma certa uniformidade fisionômica, por ela atribuída a uma perfeita compreensão por parte

(17) L. Miguel Pereira, cit. 
de Portinari do espírito do texto machadiano, no qual se configura aquela modelagem aos hábitos e preconceitos burgueses imposta à mulher pela sociedade brasileira oitocentista. Únicas exceções seriam Dona Plácida e Marcela, por pertencerem a uma outra classe social. O retrato que a crítica traça da primeira, a partir da interpretação do pintor, é bem vivo e denota a capacidade de penetração psicológica exibida por Portinari:

"No rosto redondo daquela, no lenço que lhe encobre os cabelos, na sua verruga, nos seus olhinhos empapuçados, cabem, juntas e contraditórias, a marca respeitável da triste vida de privações e canseiras e a marca aviltante das subserviências e alcovitices". ${ }^{18}$

Portinari, de fato, condensa na fisionomia de Dona Plácida a descrição que dela oferece Machado de Assis. A contradição entre uma tarefa que, a princípio, parece repugnante à mulher e a confiança que, afinal, Brás Cubas consegue conquistar transitam fluentemente de um registro para o outro:

"Custou-lhe muito a aceitar a casa; farejara a intenção e doía-lhe o oficio; mas afinal cedeu. Creio que chorava, a princípio: tinha nojo de si mesma. Ao menos, é certo que não levantou os olhos para mim durante os primeiros dois meses; falava-me com eles baixos, séria, carrancuda, às vezes triste. Eu queria angariá-la, e não me dava por ofendido, tratava-a com carinho e respeito; forcejava por obter-lhe a benevolência, depois a confiança. Quando obtive a confiança, imaginei uma história patética dos meus amores com Virgília, um caso anterior ao casamento, a resistência do pai, a dureza do marido e, não sei que outros toques de novela. Dona Plácida não rejeitou uma só página da novela; aceitou-as todas. Era uma necessidade da consciência. Ao cabo de seis meses quem nos visse a todos três juntos diria que Dona Plácida era minha sogra". ${ }^{19}$

\footnotetext{
(18) Id.

(19) Machado de Assis, cit., p. 101.
} 
Se as mulheres burguesas são apresentadas por um tratamento prototípico, Virgília, contudo, se destaca do conjunto. Portinari oferece dela uma imagem bem próxima daquela figura talhada "em pentélico, de um lavor nobre, rasgado e puro, tranqüilamente bela, como as estátuas, mas não apática nem fria". ${ }^{20}$ Os dois retratos que dela executa, de cabelo solto e possivelmente em traje de gala, e de chapéu e vestido de gola bufante, evocam, sem dúvida, uma visão mais escultórica do que gráfica. Mas não idealizada, uma vez que, sobretudo no retrato de cabelo solto, a complexidade do caráter de Virgília se impõe ao leitor de acordo com a evocação do amante:

"Era bonita, fresca, saía das mãos da natureza, cheia daquele feitiço, precário e eterno, que o indivíduo passa a outro indivíduo, para os fins secretos da criação. Era isto Virgília, e era clara, muito clara, faceira, ignorante, pueril, cheia de uns ímpetos misteriosos; muita preguiça e alguma devoção - devoção, ou talvez medo; creio que medo". ${ }^{21}$

No mesmo período em que executa as ilustrações para Memórias Póstumas de Brás Cubas, Portinari está em tratativas com Castro Maya para realizar uma tarefa semelhante para O Alienista. É o que se depreende da carta que Castro Maya lhe envia a 20 de setembro de 1943:

“Quanto ao 'Alienista' ainda não tive resposta do Jackson, mas talvez até segunda já tenha alguma cousa, de qualquer modo levarei as fotografias dos detalhes de meu quadro de Muzi para você ter uma idéia das vestimentas de 1789 no Brasil".

A idéia inicial era fazer uma edição de 500 exemplares para o conto de Machado de Assis, dos quais 100 com quatro

(20) $I d .$, p. 93

(21) Id., p. 58-59. 
águas-fortes e 13 desenhos a bico de pena e 400 com uma única gravura original e ilustrações em clichê, ${ }^{22}$ provavelmente pela Sociedade dos Cem Bibliófilos do Brasil.

Em abril de 1944, Castro Maya propõe uma nova hipótese ao artista. A tiragem seria de 400 exemplares com uma distribuição um tanto diferente da idéia inicial: 150 exemplares com 4 águas-fortes originais, 100 exemplares com uma única gravura e 150 exemplares com 2 águas-fortes. Uma carta de Mário de Andrade a Portinari, datada de junho de 1944, dá conta de que Castro Maya estava em busca de subscritores para as diferentes hipóteses de tiragem, uma vez que há uma referência à "edição principal" de O Alienista. ${ }^{23}$

O livro, afinal, acaba saindo em 1948 numa edição particular de 400 exemplares, custeada por Castro Maya para fins de beneficência. De formato grande e capa ilustrada, $O$ Alienista conta com 36 desenhos e 4 águas-fortes fora do texto e é impresso em offset na Imprensa Nacional.

Se, no caso de Memórias Póstumas de Brás Cubas, Portinari se dobra às intenções do texto machadiano, O Alienista oferece-lhe a oportunidade de ler o escritor a partir de algumas características precípuas de seu estilo pessoal. A deformação, refreada em grande parte no primeiro trabalho, é a nota dominante das ilustrações realizadas para o conto, nas quais se nota uma analogia profunda entre texto e imagem. No artigo dedicado ao lançamento do romance, Lúcia Miguel Pereira já estabelecera, de resto, uma relação entre as deformações portinarianas e a "audaciosa deformação, apenas disfarçada pela limpidez da narrativa", representada por $O$ Alienista. ${ }^{24}$

(22) Carta da W.M. Jackson Inc. a Raymundo O de Castro Maya (Rio, 29 set. 1943).

(23) Carta de Raymundo O de Castro Maya a Portinari (Rio, 4 abr. 1944); M. de Andrade, Portinari, amico mio. Campinas, Mercado de Letras-Autores Associados-Projeto Portinari, 1995, p. 135.

(24) L. Miguel Pereira, cit. 
A idéia de que Machado de Assis explora "situações-síntese", trabalha a partir de "coisas mínimas" 25 pode ser aplicada às ilustrações que o pintor elabora para o conto. O caráter tenso da narrativa machadiana ecoa na instantaneidade gráfica proposta pelo artista, que mais do que desenhos, apresenta esboços, uma espécie de primeiro estágio, de primeiro lampejo daquilo que poderia ser a imagem definitiva. As ilustrações caracterizam-se, via de regra, por um tratamento sumário e nervoso, próximo do indício e da sugestão significativa, no qual a narrativa visual se condensa em situações-limite à beira do paroxismo.

Isso não quer dizer que, em certos casos, Portinari não opte por um tratamento mais completo dos protagonistas e das cenas. É o que ocorre em duas das águas-fortes, nas quais as figuras masculinas apresentam um intenso tratamento expressionista, realçado não apenas pela procura deliberada da deformação, mas também pelos fortes contrastes entre branco e preto proporcionados pela gravura. À semelhança de Nolde, Portinari usa o preto como cor, estabelece um contraponto expressivo com o branco e, desse modo, exalta a luz que emana de um e de outro. Na outra, que representa um grupo de homens, o tratamento geométrico das figuras, reduzidas a círculos, triângulos, rombóides não de todo definidos, num escalonamento irregular que traduz o nervosismo da cena, recebe um elemento unificador e tensionador das garatujas que se sobrepõem à representação e lhe conferem um dinamismo ascensional.

A imagem que abre o livro, a de Simão Bacamarte, recebe um tratamento semelhante ao das duas águas-fortes: intensa deformação e exploração dos contrastes luminosos entre preto e branco. A figura do alienista é parcialmente geometrizada, mas isso não diminui sua força expressiva.

${ }^{(25)}$ R. Gomes, "O Alienista: loucura, poder e ciência". Tempo Social, São Paulo, 5(1-2), 1993, p. 148. 
Antes exalta-a, por encerrar as contradições de um mundo cindido, no qual Simão Bacamarte acredita representar a razão, a instância que lhe permitiria cuidar da "saúde da alma". ${ }^{26}$ Portinari encerra simbolicamente nessa imagem tão densa os diferentes estágios da trajetória psicológica do alienista: a crença inabalável no poder da ciência leva-o finalmente a tomarse como objeto dos próprios estudos, por reunir em si "a teoria e a prática", embora a derrota o aguarde no final do caminho. Morre "no mesmo estado em que entrou, sem ter podido alcançar nada". ${ }^{27}$

A decretação da insanidade da ciência pela própria ciência, sua insensatez ${ }^{28}$ parecem resumir-se na imagem proposta por Portinari, que desvela de imediato o caráter de Bacamarte, ou melhor, a falsa equação entre razão e verdade. $\mathrm{O}$ alienista é tão cindido quanto o mundo que pretende curar e isso é demonstrado sobretudo pelo contraste entre preto e branco, que podem ser considerados os pares complementares de desrazão e razão.

A "investigação de natureza política em torno do poder da ciência", que Roberto Gomes atribui à narrativa machadiana, centrada na visão da psiquiatria como "exercício de poder", ${ }^{29}$ parece estar igualmente presente na interpretação portinariana, que concede grande espaço logo às cenas corais, nas quais Bacamarte e a comunidade se confrontam dialeticamente.

Elemento não indiferente na leitura que Portinari faz de O Alienista é o tratamento anônimo conferido à maior parte de suas figuras, como que para sublinhar o papel de objetos científicos que o doutor Bacamarte lhes confere. Se o que importa, de fato, no conto é o discurso do alienista, "capaz de

\footnotetext{
(26) Machado de Assis, Helena - O alienista. São Paulo, Editora Três, 1972, p. 192.

(27) Id., p. 192.

(28) R. Gomes, cit., p. 152.

(29) Id., p. 147-148.
} 
produzir a loucura", ${ }^{30}$ os personagens só podem ser apresentados de maneira prototípica, apenas acenada, pois a lógica da ciência não conhece indivíduos, mas espécimes.

\section{2 - De Cervantes}

Uma encomenda da editora José Olympio para ilustrar Dom Quixote coloca Portinari novamente em contato com a problemática da loucura. Uma primeira edição do livro de Cervantes, com ilustrações de Gustave Doré, havia sido lançada em 1952 pela editora carioca. Em junho de 1953, José Olympio propõe ao artista "um D. Quixote em edição realmente brasileira, ilustrado pelo grande Portinari”. Entusiasmado com o convite, o pintor planeja uma viagem à Espanha para estudar o cenário das façanhas do fidalgo e de seu escudeiro mas é obrigado a desistir da idéia por motivos de saúde. ${ }^{31}$

Isso não significa que o projeto seja deixado de lado, como mostra uma carta do editor, datada de julho de 1954. Nela, José Olympio reclama do fato de Portinari não deixar "nenhum tempinho para nós (...) isto é, para as figuras do grande e imortal livro de Cervantes". ${ }^{32}$ É provável que a demora na execução dos desenhos tenha sido motivada pelas grandes encomendas que o pintor estava realizando naquele momento, sobretudo os painéis Guerra e Paz para a sede das Nações Unidas em Nova Iorque. É o que assinala uma carta a Flávio Motta, na qual Portinari escreve:

"Eu tenho trabalhado muito. A 'Guerra' está pronta e um pedaço da 'Paz'. Para descansar, estou ilustrando o D. Quixote, o que me tem divertido muito". ${ }^{33}$

\footnotetext{
(30) Id., p. 150.

(31) Carta de José Olympio a Portinari (Rio, 1 jun. 1953); "Nota da editora", in: C. Portinari, Poemas. Rio de Janeiro, José Olympio, 1964, p. 8.

(32) Carta de José Olympio a Portinari (Rio, 8 jul. 1954).

(33) Carta de Portinari a Flávio Motta (Rio, 20 set. 1955).
} 
Não são claros os motivos pelos quais Portinari, mesmo tendo executado 22 desenhos entre 1955 e 1956, não os tenha entregue à editora, frustrando o projeto de um $D$. Quixote integralmente nacional. Reduzidos a 21 , após um roubo sofrido durante uma exposição em Paris em março-abril de 1957, os desenhos são adquiridos por Raymundo de Castro Maya pouco depois da morte do pintor.

Com uma outra proposta editorial, que inclui pequenos trechos do livro de Cervantes e glosas poéticas de autoria de Carlos Drummond de Andrade, os 21 desenhos de Portinari são divulgados por três edições nacionais: pela Diagraphis (1972-73) e pela Fontana (1973) em tamanho original e novamente pela Diagraphis (1973-74) em tamanho reduzido. ${ }^{34}$

Executados com lápis de cor, os desenhos de D. Quixote mostram um Portinari bem diferente do intérprete de Machado de Assis. O intenso cromatismo da série, na qual predominam amarelos e azuis; o desenho, não raro, ingênuo em suas simplificações expressivas denotam um outro momento da trajetória artística de Portinari, transposta para a interpretação das aventuras do cavaleiro espanhol. A saturação cromática que caracteriza o conjunto não deixa de ter parentesco com obras como A Primeira Missa no Brasil (1948), na qual o amarelo em vários matizes é a nota dominante da composição; os painéis Guerra e Paz (1952-1956), nos quais predominam azuis e amarelos; alguns desenhos da série "Israel" (1956); e algumas experiências com a abstração geométrica ensaiadas naquele mesmo período.

Leitor atento de Cervantes, Portinari cria um D. Quixote fiel à descrição do livro - um homem de cinqüenta anos, "rijo

${ }^{(34)}$ C. H.. Knychala informa que, em 1978, é feita uma nova edição do livro com uma tiragem de 1000 exemplares, dos quais $50 \mathrm{com}$ a assinatura de Carlos Drummond de Andrade. Ver: O livro de arte brasileiro, cit., p. 125. Em 1985, a Secretaria de Educación Pública Dirección General de Publicaciones e Medios, do México, edita uma versão em espanhol do livro. 
de compleição, seco de carnes, enxuto de rosto", ${ }^{35}$ a evocar mais um inseto que um ser humano nos poucos traços que o definem. A ele contrapõe-se a robusta corporeidade de Sancho Pança, homem "de pouco sal na moleira", ${ }^{36}$ cuja pequena inteligência transparece no rosto atônito e no olhar perdido diante das inúmeras promessas do fidalgo. A terceira figura central da narrativa, Rocinante, apresenta variações cromáticas nas diferentes cenas, mas há alguns elementos unificadores que permitem reconhecê-lo - o aspecto de brinquedo de encaixe e o tracejado do manto, a evocar hachuras.

O cavalo mais interessante do conjunto não é, porém, Rocinante. É Clavilenho, "um pedaço de lenho" que tem "uma clave ou escaravelha na testa", com o qual D. Quixote e Sancho Pança acreditam estar voando. O caráter irreal da cena descrita por Cervantes, com o magro fidalgo a evocar "uma figura de tapeçaria flamenga, pintada ou tecida nalgum triunfo romano", ${ }^{37}$ ganha uma interpretação lírica de Portinari. O cavalo, definido por zonas geométricas, alça-se num céu simultaneamente diurno e noturno, no qual o azul e o amarelo se fundem harmonicamente, criando duas grandes áreas de saturação cromática. Citação do cavalo de Guernica, Clavilenho, branco e cinza, carrega na garupa um D. Quixote que mais parece um gafanhoto com sua carapaça negra, quase desencarnado, e um roliço Sancho Pança, aviltado pelo medo e reduzido quase a uma bola. A credulidade de D. Quixote, o dominio absoluto do ideal sobre o real, a ponto de não perceber a burla de que era alvo, aglutinam-se nessa que é provavelmente a ilustração mais expressiva da série. Nela Portinari parece enfeixar sua visão irônica e carinhosa do cavaleiro, que acredita no sonho e não percebe que o vôo é apenas fruto da imaginação e de alguns truques baratos.

${ }^{(35)}$ M. de Cervantes, Dom Quixote. São Paulo, Nova Cultural/Círculo do Livro, 1993, p. 29.

(36) Id., p. 53.

(37) Id., p. 469, 473 
Concentrando a representação no momento da mais pura ilusão, o pintor faz interagir cavalo e cavaleiros numa composição definida horizontalmente, tanto pela distensão do primeiro, captado no momento do galope, quanto pela lança de D. Quixote que amplifica as linhas direcionais do desenho ao enfatizar a abertura do campo visual à esquerda. O efeito de tapeçaria de que fala Cervantes pode ser encontrado no tratamento bidimensional dado à cena, na qual fundo e primeiro plano constituem uma dimensão única, a sublinharem ainda mais a irrealidade da situação.

O aspecto etéreo dado à figura de D. Quixote pode ser considerado um recurso expressivo de que o artista lança mão para criar um contraponto entre o devaneio do fidalgo e o princípio de realidade que domina os demais personagens do enredo visual. Tudo em D. Quixote é diferente do resto da humanidade: a figura ossuda, negra e vermelha, de olhos arregalados, cabelo, barba e bigode em desalinho, parece pertencer mais ao reino das aparições do que à ordem terrena.

A composição definida horizontalmente, que é a nota dominante da série, é quebrada por algumas representações verticais e sobretudo pelo escorço de Sancho Pança insone. O encurtamento da figura, sua redução a uma forma redonda, o contraste entre o vermelho e um negro prevalentemente azulado, a adesão de Sancho Pança ao fundo amarelo com algumas faixas marrom criam uma cena de grande impacto visual. Definida, em primeiro lugar, pela cor que é o elemento dominante do conjunto e o verdadeiro definidor da robusta corporeidade do escudeiro.

Um outro desenho bem significativo é o do episódio dos moinhos de vento, no qual D. Quixote e Rocinante são representados no final da refrega, quando o vento, ao impulsionar a vela "com tanta fúria, (...) fez a lança em pedaços, levando desastradamente cavalo e cavaleiro, que foi rodando miseravelmente pelo campo afora". Um D. Quixote atônito e sem condições de se mover, "tal fora o trambolhão que dera com o 
cavalo", e um Rocinante, "também meio desazado", ${ }^{38}$ ocupam a parte direita da composição num alinhamento simétrico à vela do moinho, criando um jogo de linhas transversais, reforçado pela sutil linha negra da lança que atravessa o lado esquerdo e proporciona uma impressão de dinamismo estático.

A cena do ataque às ovelhas, por ser resolvida bidimensionalmente, cria uma imbricação entre D. Quixote e os animais, que traduz eficazmente a imagem proposta por Cervantes do cavaleiro que "se entranhou" pelo rebanho e "começou a alancear nelas, tão denodado como se desse em verdadeiros inimigos mortais". ${ }^{39}$ A entrada rebanho adentro é articulada num esquema cruciforme, dominado pela vertical constituída por D. Quixote, à qual se sobrepõem três verticais menores (Sancho Pança e dois pastores) que possibilitam visualizar o desenrolar do episódio em vários momentos sucessivos - a admoestação do escudeiro, o ataque ao rebanho, o revide dos ovelheiros -, numa seqüência de derivação cinematográfica.

Igualmente determinado por um ritmo vertical e temporalmente escandido é o episódio do javali. A fuga de Sancho Pança para o carvalho é resumida no momento em que este, pendurado a um galho, grita por socorro, com o amo assistindo a tudo. A composição é dominada por azuis e verdes, dispostos em faixas parcialmente geométricas, aos quais fazem contraponto o negro de D. Quixote e do javali, o cinza do asno e as diferentes cores de Sancho Pança e de um cavaleiro. O escorço do escudeiro é o centro nevrálgico do desenho, dividido em duas metades simétricas e equilibradas entre si, apesar da sensação de apinhamento do lado esquerdo. A sugestão da floresta pelo segundo tronco, a pedra e o asno contrabalançam, contudo, a outra metade, criando um equilíbrio que transporta o olho do observador diretamente para a figura de Sancho Pança.

(38) Id., p. 55.

(39) Id., p. 100. 
Em alguns fundos amarelos da série, Portinari evoca o traço espesso e sulcado de Van Gogh e o movimento de seus céus, talvez para melhor sublinhar o caráter irreal dos episódios narrados.

\section{3 - De Staden}

Se as ilustrações para os livros de Machado de Assis e Cervantes cumprem seu papel de divulgadoras de uma interpretação crítica e poética do texto literário, o mesmo não acontece com o conjunto de 25 desenhos, realizado em 1941 para Duas Viagens ao Brasil, de Hans Staden. A não-divulgação das ilustrações é resultado do conflito que se instaura entre Portinari e George Macy, diretor de The Limited Editions Club, de Nova Iorque, por uma razão que poderia ser definida nos termos de uma diferente visão daquilo que deveria ser uma "ideologia visual". ${ }^{40}$

Interessado em publicar o livro de Staden, que seria ilustrado e impresso no Brasil, de acordo com as diretrizes de The Limited Editions Club, que pedia a colaboração profissional de artistas e editores do país ao qual a obra fazia referência, Macy entra em contato com Portinari por indicação de José Olympio. O contato, iniciado em setembro de 1940, ganha contornos positivos dois meses mais tarde, após a aceitação da encomenda por parte do pintor:

"Acredito que, para nós, o melhor livro a ser impresso no Brasil é a Verdadeira História de Hans Staden. É a his-

\footnotetext{
(40) Alguns desenhos foram divulgados no artigo de A Fabris, "Os canibais censurados", publicado em Nossa América (São Paulo, 4, nov.-dez. 1991). Uma versão reduzida do artigo, com vários desenhos, foi divulgada por Ciência Hoje (Rio de Janeiro, 86, nov.-dez. 1992), sob o título de "Portinari e os tupinambá. A antropofagia recusada". 23 desenhos foram exibidos na exposição "Índios no Brasil", organizada em 1992 pela Secretaria Municipal de Cultura de São Paulo.
} 
tória de um alemão que foi capturado pelos selvagens no século XVI. Trata-se de uma história extraordinariamente bela. (...) Se o senhor estiver interessado em fazer ilustrações para esse livro, a tarefa de fazer as ilustrações será deixada completamente em suas mãos. Pagar-lhe-emos nosso honorário-padrão de mil dólares; isso é para o direito de reprodução das imagens, uma vez que os desenhos originais lhe serão devolvidos". ${ }^{41}$

Numa entrevista com Macy, Portinari faz uma primeira sugestão para as ilustrações - realizar litografias ou monotipias a serem reproduzidas litograficamente e coloridas à mão. O artista expressa também sua preferência por um certo tipo de formato, mas o editor americano resolve propor um primeiro boneco que indicaria o que The Limited Editions Club esperava de seus parceiros brasileiros. Em contrapartida, caberia a eles elaborar um outro boneco, no qual seriam evidenciados o papel e os tipos a serem usados, a colocação exata das ilustrações e a encadernação pretendida. Sabedor de que o Brasil poderia ter dificuldades para obter papel de boa qualidade, em virtude da guerra, Macy propõe-se a enviar papel ou o material necessário para fazê-lo diretamente dos Estados Unidos. Ao encaminhar o boneco a José Olympio, em abril de 1941, Macy preocupa-se em fazer um reparo, que parece sinalizar o interesse de sua editora em realizar um trabalho harmonioso com Portinari:

"O problema seguinte é o do papel a ser usado. O senhor verá que usamos em nosso boneco um papel bem grosseiro e quase da cor do café. É provável que o Senhor Portinari não goste da superficie do papel, ou da cor; estarei de acordo se ele preferir um papel com um acabamento mais liso ou um papel de cor branca que dê um melhor fundo a suas imagens". 42

(41) Carta de George Macy a Portinari (26 nov. 1940).

(42) Cartas de George Macy a José Olympio (6 dez. 1940; 7 abr. 1941). 
Em setembro, quando o pintor se encontrava em Washington para realizar as têmperas da Fundação Hispânica, Macy volta a discutir a questão do boneco diretamente com ele. Como Portinari não gostara da proposta da editora, Macy sugere-lhe elaborar um novo projeto e mostra-se ansioso em saber do andamento das ilustrações. ${ }^{43}$ Quando estas lhe são encaminhadas em novembro, não esconde sua decepção: não correspondiam às litografias e desenhos de índios que vira na exposição de Portinari realizada pelo Museu de Arte Moderna de Nova Iorque (1940) e que haviam sido o estopim da encomenda. O que Macy pretendia é dito claramente no final da carta que envia ao artista para recusar os desenhos e solicitar a elaboração de uma nova proposta:

"Mas eu estava esperando ter do senhor algumas paisagens simples do país no qual Hans Staden se encontrava quando foi capturado pelos canibais e alguns desenhos simples ou litografias dos índios daqueles dias". rodeios:

O motivo do desagrado é igualmente explicitado sem

"Quando examinei pela primeira vez esse pacote de desenhos, pensei que provavelmente o senhor estava tentando fazer pinturas que se pareceriam com as pinturas feitas pelos canibais que Hans Staden encontrou. Pareceu-me uma boa idéia, mesmo que alguns leitores do livro não a achassem agradável. Mas tive que descartar essa idéia quando percebi que o senhor havia colocado uma leve camada de tinta sobre muitos dos desenhos; pois a tinta, com certeza, priva os desenhos de sua inteligente qualidade primitiva. Pensei também que o senhor deu ênfase demasiada à carnificina e à brutalidade do livro; o livro não é totalmente repleto desse tipo de horror". ${ }^{44}$

(43) Carta de George Macy a Portinari (26 set. 1941).

(44) Id. (13 nov. 1941). 
Portinari recusa-se a executar novos desenhos, afirmando que as ilustrações propostas eram "boa arte", ${ }^{45}$ o que leva o editor a fazer uma nova tentativa. Os argumentos usados são bastante interessantes, pois estabelecem uma distinção nítida entre arte pura e arte aplicada:

"Qualquer um sabe que o verdadeiro artista é o artista que pinta para sua própria satisfação e não para a satisfação de um público; se tentasse pintar para um público, seria incapaz de pensar o que pintar. Mas, com certeza, este, que é um dos princípios básicos da arte, deve ser um princípio que se aplica apenas à pintura.

Quando o senhor faz um quadro, o senhor cria um objeto de arte único, para sua própria satisfação. No entanto, quando o senhor se compromete a fazer ilustrações para um livro, e quando essas ilustrações devem ser reproduzidas mil e quinhentas vezes, não é possivel concluir que todos os mil e quinhentos objetos de arte são feitos para agradar o senhor e não para agradar mais ninguém. (...) Creio ser uma parte necessária de sua feitura das imagens que elas agradem a mim, ao tipógrafo e a um grande número de nossos membros. Pensei que isso estivesse claramente entendido. Realmente, embora no contrato as ilustrações sejam deixadas à sua discrição, no que concerne à técnica, declara-se no contrato que o ilustrador concordou que as ilustrações seriam feitas de modo a satisfazer o editor". ${ }^{46}$

Portinari não responde a esse apelo e nem àquele feito em fevereiro de 1942, guardando as ilustrações censuradas que, ao que parece, seriam divulgadas pela primeira vez num livro que Mário de Andrade deveria escrever para a editora Losada, de Buenos Aires, em 1943. ${ }^{47}$

Paradoxalmente, o que gera o contraste entre Portinari e Macy é o fato de o pintor ter interpretado realmente o texto

(45) Carta de Cândido Portinari a George Macy (s.d.).

(46) Carta de George Macy a Portinari (28 nov. 1941).

${ }^{(47)}$ M. de Andrade, cit., p. 116, 124. 
de Staden e não ter proposto a visão estereotipada esperada pelo editor. O caráter desmistificador da narrativa de Staden, que apresenta índios selvagens, nus, ferozes e antropófagos, e não as criaturas edênicas ou fantásticas de muitos relatos de viajantes, é plenamente assimilado por Portinari, que se vale de um desenho primitivo, regressivo, não raro canhestro para melhor sublinhar a visão do prisioneiro dos tupinambá.

O pintor não se limita a ler o texto de Staden. Estuda também as gravuras da primeira edição do livro (Marburgo, 1557), feitas provavelmente sob supervisão direta do autor, cuja estrutura praticamente reproduz em alguns momentos. O que diz a narrativa de Staden? E o que mostram as imagens? A visão do vencido:

"Prisioneiro. No coração da tribo. No vazio. Ele é o alimento conquistado e oferecido. Morte a prazo. Objeto e pessoa. Ator trágico. Espectador permanente de seu próprio suplício. De sua própria devoração anunciada, repetida, reafirmada. (...) Longa oscilação de nove longos meses entre a esperança e a desesperança, o sol e a chuva, o diálogo e a solidão, o caçador e a caça, a terra e a água. E quanto mais profunda é sua solidão nessa aldeia-gaiola e lar eriçado de inquietude e terror, tanto mais agudo é seu olhar. Quanto mais o desespero cresce, tanto mais o espreitador trágico e nu, atento ao que o espera, se abre inteiro ao mundo fascinante e cruel da tribo". ${ }^{48}$

É essa visão de dentro, que não conforma o índio aos padrões idealizados do Renascimento e do Maneirismo, que Portinari esposa, atento a dar consistência plástica às várias anotações de seu personagem. Em primeiro lugar, a alteridade absoluta que o prisioneiro confere ao índio, cujos hábitos e atividades observa, colocando-se na posição de quem deve tentar compreender uma cultura estranha a fim de sobreviver e criar uma função para si dentro dela.

${ }^{(48)}$ M. Bouyer, "Des sauvages et des images", in: H. Staden, Nus, féroces et antropophages. Paris, Éditions du Seuil, 1990, p. 7-8. 
Por isso, o artista dá pouca atenção ao lugar da ação, que se reduz praticamente à aldeia. O que lhe interessa, antes de tudo, é elaborar um conjunto de imagens que dêem conta de uma narrativa pontual de acontecimentos cotidianos, de regras sociais organizadas, mesmo se reprováveis aos olhos de um cristão. A narrativa portinariana, com exceção das imagens do navio, se concentra no cativeiro e, portanto, no encontro de Staden com os tupinambá, do qual destaca alguns momentos significativos: o aprisionamento, a chegada à aldeia, o ataque a Ubatuba, a doença do cacique Nhaêpepô-oaçu, o ritual antropofágico, a maneira de pescar, o uso de um instrumento de corte adquirido dos cristãos.

As cenas de antropofagia, que chocaram Macy, ocupam o lugar devido na seqüência elaborada por Portinari. Num total de cinco, traduzem fielmente o tom frio da narrativa de Staden, dando um ar natural a seus protagonistas, entretidos num ato normal para sua cultura. Desse conjunto de imagens três se destacam justamente pela adesão ao estilo de Staden: os despojos do escravo carijó, o esfolamento de um cadáver e o banquete de Cunhambebe. Confrontando a representação de Cunhambebe proposta por Portinari com o relato de Staden, é possivel afirmar que, em certos momentos, o artista vai além das intenções do marinheiro alemão, ao retirar qualquer juízo moral de sua interpretação da antropofagia. Se Staden admoesta Cunhambebe por estar devorando um semelhante, sentindo-se incomodado com sua resposta ${ }^{49}$ Portinari, ao concentrar a ação de sua cena na figura do índio, focaliza tão-somente um dos momentos do

${ }^{(49)}$ H. Staden, Duas viagens ao Brasil. Belo Horizonte, Itatiaia; São Paulo, EDUSP, 1974, p. 132 ("Durante isto Cunhambebe tinha à sua frente um grande cesto cheio de carne humana. Comia de uma perna, segurou-m'a diante da boca e perguntou-me se também queria comer. Respondi: 'Um animal irracional não come um outro parceiro, e um homem deve devorar um outro homem?'. Mordeu-a então e disse: 'Jauára ichê'. 'Sou um jaguar. Está gostoso'. Retirei-me dele, à vista disto”). 
ritual antropofágico, aquele que reserva aos homens da tribo a devoração do tronco do inimigo sacrificado.

Os indios que Portinari desenha para a narrativa de Staden são bem diferentes daqueles que haviam chamado a atenção de Macy na exposição de Nova Iorque. Se estes são resultado de um trabalho documental, visando a elaboração dos painéis para o edifício do Ministério da Educação e Saúde, os das ilustrações se conformam à visão de Staden, sendo apresentados como figuras rudes e primitivas, graças a um desenho sintético, que lança mão de deformações e de simplificações, sem temer enveredar pelo antigracioso.

Objeto e sujeito de uma experiência ímpar, Staden é representado por Portinari em seu duplo papel através de duas diferentes visões do corpo. Enquanto o sujeito é um corpo inteiro, o objeto se reduz a uma silhueta, a um simples arabesco na chegada à aldeia, por ter perdido toda qualidade humana.

Intérprete fiel de Staden, Portinari não deixa de conceder-se, contudo, algumas licenças poéticas, enveredando, como no caso da morte do índio carijó, por uma interpretação "onírica" da antropofagia. O relato objetivo do prisioneiro, que só faz referência ao decepamento da cabeça, atirada fora pela má aparência do rosto do índio, ${ }^{50}$ transforma-se em Portinari numa verdadeira operação de desmontagem de um corpo, levando o leitor a perceber sucessivamente uma mão, um pé, um pedaço de tronco, um olho, a cabeça sustentada por alguns ossos, na qual se percebe um esgar de dor na boca entreaberta.

Portinari não poderia concordar com o pedido de reconsideração de Macy porque tinha consciência de que o ilustra-

(50) Id., p. 121 ("Decepou-lhe a cabeça, pois o carijó tinha só um olho e tinha má aparência, por causa da moléstia que tinha tido. Atirou fora a cabeça, chamuscando a pele do corpo sobre o fogo. Picou-o depois, repartindo-o com os outros em partes iguais, como é usado entre eles. Consumiram-no todo, menos a cabeça e tripas, das quais tiveram nojo, porque estava doente"). 
dor moderno é um verdadeiro intérprete do texto literário, para o qual propõe não imagens aproximativas ou estereotipadas, mas uma visão aderente à ideologia do autor, cujas palavras transforma em ilustrações capazes de traduzir com poucos traços situações, não raro, complexas. Para tanto, não teme mudar o registro expressivo de um conjunto para outro, sabedor de que o artista está a serviço do autor, embora não abdique de sua personalidade estilística. Trabalho coletivo, pois, e não visão personalista, como pretendia Macy, que não percebe que Portinari estava interpretando Staden e levando em conta as diretrizes estruturais de sua narrativa, para a qual só poderia propor imagens cruentas e primitivas, as que melhor respondiam às imagens verbais contidas em Duas Viagens ao Brasil.

ABSTRACT: As an illustrator Portinari achieves a reading of a book faifthfull to the mind of the author. The illustrations made for books by Machado de Assis, Cervantes and Staden, in which is apparent a deep identification between text and image, confirm this attitude.

Keywords: modern illustration, Portinari, Machado de Assis, Cervantes, Staden. 